\title{
Dynamics of Granule Cell Migration: A Confocal Microscopic Study in Acute Cerebellar Slice Preparations
}

\author{
Hitoshi Komuro and Pasko Rakic \\ Section of Neurobiology, Yale University School of Medicine, New Haven, Connecticut 06510
}

\begin{abstract}
Real-time examination of Dil-labeled, immature granule cells in cerebellar slice preparations reveals several temporal and cytological aspects of neuronal migration that have not been observed in previous in vivo or in vitro systems. Using confocal microscopy we have obtained evidence that rates of cell movement depend critically on the age of the cerebellum. Although there were considerable variations in the speed of individual cells, the average rate of cell migration increased systematically from $9.6 \pm 3.0 \mu \mathrm{m} / \mathrm{hr}$ in cerebella from 7-d-old mice to $18.0 \pm 2.9 \mu \mathrm{m} / \mathrm{hr}$ in cerebella from 13 d-old mice. Consequently, granule cells traversed the developing molecular layer within a relatively constant time period despite the doubling in width of the molecular layer during the second week of postnatal life. Granule cell movement was characterized by alternations of short stationary phases with movement in a forward or backward direction. The net displacement of a cell depended on the duration and frequency of these phases as well as on the speed of movement. Changes in the relative position of Dil crystals attached to the surface of granule cells suggested the existence of a complex topographical flow of plasma membrane during migration. Although a large portion of the plasma membrane seemed to move in register with the nucleus and surrounding cytoplasm, new membrane appeared to be incorporated primarily at the leading process. However, the pattern of membrane flow at the interface between migrating neurons and Bergmann glial fibers could not be determined, since these sites could not be labeled by Dil crystals. The present results are in harmony with the concept that multiple cellular/molecular mechanisms may be engaged in granule cell migration.
\end{abstract}

[Key words: cerebellar development, neuronal cell migration, confocal microscopy, brain slice preparation, fluorescent carbocyanine dye, cell movement ratel

In the developing brain, postmitotic neurons migrate from their place of origin to distant final destinations (Rakic, 1972; Sidman and Rakic, 1973). This directed, active displacement of immature neurons is essential for establishing normal cytoarchitecture and synaptic connectivity in the vertebrate brain (Cav-

\footnotetext{
Received Feb. 28, 1994; revised July 8, 1994; accepted July 18, 1994.

This research was supported by the U.S. Public Health Service Grants NS 14841 and NS 22807. We thank Drs. R. Cameron, D. Kornack, and K. Wikler for useful suggestions and comments on the manuscript.

Correspondence should be addressed to Dr. Hitoshi Komuro, Section of Neurobiology, Yale University, School of Medicine, 333 Cedar Street, New Haven CT 06510.

Copyright (C) 1995 Society for Neuroscience $0270-6474 / 95 / 151110-11 \$ 05.00 / 0$
}

iness and Rakic, 1978; Hatten, 1990; Rakic, 1990). In cerebellar cortex, for example, granule cells migrate from the external granular layer where they are generated, crossing the expanding molecular layer to reach their final position in internal granular layer (Ramon y Cajal, 1911; Miale and Sidman, 1961). Electron microscopic analysis suggested that granule cell migration may be guided and their movement facilitated by interactions with the elongated processes of Bergmann glial cells (Rakic, 1971). Subsequent studies have supported the concept that functional interactions between postmitotic granule cells and Bergmann glial fibers are essential for neuronal migration (Rakic and Sidman, 1973a,b; Rakic, 1976, 1981; Hatten et al., 1984, 1986; Gao and Hatten, 1993). Recently, scveral molccular and cellular mechanisms have been implicated in the directed movement of granule cells, including cell-cell recognition and adhesion, intracellular $\mathrm{Ca}^{2+}$ dynamics, and activity of NMDA receptors (Antonicek et al., 1987; Edmondson et al., 1987; Gloor et al., 1990; Fishell and Hatten, 1991; Komuro and Rakic, 1993a,b; Cameron and Rakic, 1994; Farrant et al., 1994; Rakic et al., 1994).

One major impediment in examining the role of different molecules in cell movement is the availability of reliable functional assays of neuronal migration. During the last three decades, several features of migrating granule cells have been analyzed, first using in vivo and more recently in vitro assay systems. In initial studies, ${ }^{3} \mathrm{H}$-thymidine autoradiography was used to reveal the spatiotemporal pattern of granule cell movement in vivo (Miale and Sidman, 1961; Fujita, 1967; Altman, 1969). Dissociated cell culture systems were subsequently developed to allow direct observations of granule cell movement in vitro (Trenkner and Sidman, 1977; Hatten, 1985; Edmondson and Hatten, 1987; Gregory et al., 1988). Recently, granule cell movement has been examined using a microexplant culture system (Moonen et al., 1982; Nagata and Nakatsuji, 1990).

Although studies using dissociated cell and microexplant culturc systcms have provided valuable information about possible mechanisms that underlie granule cell migration, these systems do not retain the ambient cellular and molecular environment that normally affects cell migration. For example, cerebellar granule cells in vivo migrate in a stereotypical and unidirectional fashion away from the external granular layer. However, in both dissociated cell and microexplant culture systems, granule cells migrate bidirectionally along the process of the glial cells as well as on the bundles of neurites.

To study molecular and cellular mechanisms underlying granule cell migration, it is essential to develop an in vitro system that both faithfully replicates neuronal migration in vivo, and permits a microanalysis of migrating cell behavior. To achieve 
this goal, several slice culture systems have been developed (Hemmendinger and Caviness, 1988; Komuro and Rakic, 1992, 1993a; O'Rourke et al., 1992; Fishell et al., 1993; Roberts et al., 1993). In the present study, the migration of fluorescently labeled granule cells was examined in cerebellar slice preparations from postnatal mice using a laser scanning confocal microscope. This approach revealed several spatial and temporal charactcristics of granulc cell movement that should be taken into account in considering the mechanism of cell migration.

\section{Materials and Methods}

Postnatal day (P) 7-13 mice (CD-1) were killed by decapitation, in accordance with institutional guidelines. Cerebella were quickly removed from the skull and placed in cold $\left(5^{\circ} \mathrm{C}\right)$ Hanks' balanced salt solution (40 mM glucose, $2.5 \mathrm{~mm}$ Hepes) that was oxygenated with $95 \%$ $\mathrm{O}_{2}, 5 \% \mathrm{CO}_{2}$ to a final $\mathrm{pH}$ of 7.4. Prior to cutting, cerebella were embedded in $20 \%$ gelatin and sectioned sagittally into $300-400 \mu \mathrm{m}$ thick slices on a Vibro Slice microtome (Stoelting Co.). After sectioning, pia mater and gelatin were carefully removed under a dissecting microscope. Only slices obtained from the middle region of the cerebellum were used for this study. To label migrating granule cells, cerebellar slices were incubated for $30 \mathrm{~min}$ at $37^{\circ} \mathrm{C}$ in a fluorescent lipophilic carbocyanine dye $\left[1,1^{\prime}\right.$-dioctadecyl-3,3,3',3'-tetramethylindocarbocyanine perchlorate (Dil)] $(10 \mu \mathrm{g} / \mathrm{ml}$ ) (Molecular Probes) added to the cell culture medium (Honig and Hume, 1986). The incubation medium consisted of minimum essential medium (Gibco) supplemented with $40 \mathrm{~mm}$ glucose, $1.8 \mathrm{~mm}$ glutamine, $24 \mathrm{~mm} \mathrm{NaHCO}$, penicillin $(90 \mathrm{U} / \mathrm{ml})$, and streptomycin $(90 \mu \mathrm{g} / \mathrm{ml})$. After rinsing with the incubation medium, brain slices were maintained in an incubator $\left(37^{\circ} \mathrm{C}, 95 \%\right.$ air, $\left.5 \% \mathrm{CO}_{2}\right)$ for an additional $2-4 \mathrm{hr}$. Brain slices were then transferred into the chamber of a microincubator (PDMI-2, Medical System Corp.) attached to the stage of an inverted microscope (IMT-2, Olympus Corp.). Chamber temperature was kept at $37.0 \pm 0.5^{\circ} \mathrm{C}$ using a temperature controller (TC-202, Medical System Corp.), and the slices were provided with constant gas flow $\left(95 \% \mathrm{O}_{2}, 5 \% \mathrm{CO}_{2}\right)$. To prevent movement of the slice preparation during observation, a nylon net glued to a small silver wire ring was placed over the preparations.

A laser scanning confocal microscope (Bio-Rad, MRC-600) was used to visualize migrating granule cells labeled with $\mathrm{DiI}$ in the slices. The tissue was illuminated with $514 \mathrm{~nm}$ wavelength light from an argon laser through an epifluorescence inverted microscope equipped with a $40 \times$ water-immersion objective (Zeiss, numerical aperture 0.75 ). Light passing through the aperture was filtered by a $550 \mathrm{~nm}$ long-pass filter. To protect the migrating granule cells labeled with DiI from any cytotoxic effect of the laser beam, neutral density filters were added to reduce the excitation light level by $99 \%$. If no movement of granule cells was detected during the first $30 \mathrm{~min}$ of observation, the brain slice was discarded. Shock to the tissue during sectioning of slices can disrupt cell movement and prevent most cells from migrating. Accordingly, the present study is based on the analysis of approximately one-fifth of the most healthy slices which displayed sustained cell migration. This sampling procedure favored slices in which cells displayed visible and robust movement shortly after sectioning. Since the mode and speed of granule cell movement in slices resembled those in vivo (Fujita, 1967), we presume that other cytological and temporal parameters of migration are analogous to the in vivo situation. Images of the migrating granule cells in a single focal plane were collected with laser scans every 1 or $10 \mathrm{~min}$ for up to $5 \mathrm{hr}$, and recorded on an optical disk recorder (TQ-3031, Panasonic) or an optical drive (cosmos 600, Racet).

\section{Results}

\section{Mode and rate of cell movement}

The laser scanning confocal microscope allowed us to identify DiI-labeled migrating granule cells in the molecular layer of the slice preparation. Because DiI crystals are incorporated into the plasma membrane, the fluorescent images accurately displayed cell body contours. Migrating granule cells in our preparations had a characteristically small spindle-shaped body, a thin trailing process, and a more voluminous leading process, such as described by Ramon y Cajal (1911) using a Golgi-impregnation method. In most instances the leading process extends first, and the nucleus and surrounding cytoplasm descend within the membrane envelope to the next position. Since the entire leading process including the attenuated tip is often difficult to visualize, the rate of granule cell migration in the present study was calculated by measuring the distance between the lower margin of the cell soma and selected stationary elements in the slice preparation. Figure $1 A$ shows an cxample of a Dil-labclcd granulc cell in the molecular layer of a postnatal 9-d-old (P9) mouse cerebellum visualized $2 \mathrm{hr}$ after staining, and recorded in optical sections collected at $10 \mathrm{~min}$ intervals. As shown at lower-power magnification (Fig. 1B), this particular granule cell indicated by a black asterisk was located approximately $15 \mu \mathrm{m}$ below the slice surface, and was closely apposed to the process of a Bergmann glial cell indicated by white arrowheads. All migrating granule cells were closely apposed to Bergmann glial fibers; a single Bergmann glial process was often contacted by two migrating granule cells (Fig. $1 B$ ). The cell body of the migrating granule cell in Figure $1 A$ was initially $12 \mu \mathrm{m}$ long and $4 \mu \mathrm{m}$ wide. However, the cell changed its shape during its movement, possibly because of squeezing past various obstructions in its environment. During the observation period, the cell body of the granule cell gradually translocated along the Bergmann glial fiber toward the internal granular layer (Fig. $1 A$ ).

The rate of granule cell movement is closely related to the tempcrature of the culture medium; lowering the medium tcmperature slowed cell movement $(\mathrm{H}$. Komuro and P. Rakic, unpublished observation). Therefore, all experiments in the present study were carried out at $37.0 \pm 0.5^{\circ} \mathrm{C}$, To analyze the dynamic pattern of cell movement, we plotted the distance traversed by the granule cell as a function of elapsed time. For example, the cell shown in Figure $1 A$ moved a total distance of $21.0 \mu \mathrm{m}$ toward the internal granular layer during the $2 \mathrm{hr}$ of recording (Fig. 2). Therefore, the overall rate of this cell movement was $10.5 \mu \mathrm{m} / \mathrm{hr}$. However, the displacement of the migrating granule cell ranged between $0-2.8 \mu \mathrm{m}$ for each $10 \mathrm{~min}$ time-bin recording.

The overall rate of granule cell movement in slice preparations obtained from 51 postnatal P7-13 mouse cerebella ranged between $6-24 \mu \mathrm{m} / \mathrm{hr}$, and the average rate was $13.9 \mu \mathrm{m} / \mathrm{hr}$. This rate of movement is comparable to the rate based on changes in position of cells labeled with ${ }^{3} \mathrm{H}$-thymidine in a series of intact animals (Fujita, 1967). Furthermore, this rate of movement is similar to the rate obtained from dissociated ccrcbcllar granulc cells of comparable age in coculture experiments (Fishell and Hatten, 1991), and with data obtained from microexplant cultures of the mouse cerebellum of similar age (Komuro and Rakic, 1993b).

\section{Age-dependent change in the rate of cell movement}

After establishing that the average rate of cell movement in slices was not adversely affected by the in vitro conditions for the first several hours, we examined the rate of granule ccll movement over the course of postnatal development. More than 100 cerebellar slices obtained from P7-13 mice were examined for a period between $30 \mathrm{~min}$ and $5 \mathrm{hr}$ using laser scanning confocal microscopy, In slices obtained from P8 (Fig. 3A), P10 (Fig. $3 B$ ), P11 (Fig. 3C), and P12 (Fig. 3D), the somata of migrating granule cells moved vertically across the molecular layer toward the internal granular layer. Although we did not observe distinct differences in the size or morphology between migrating granule cells at different postnatal days, we found a 

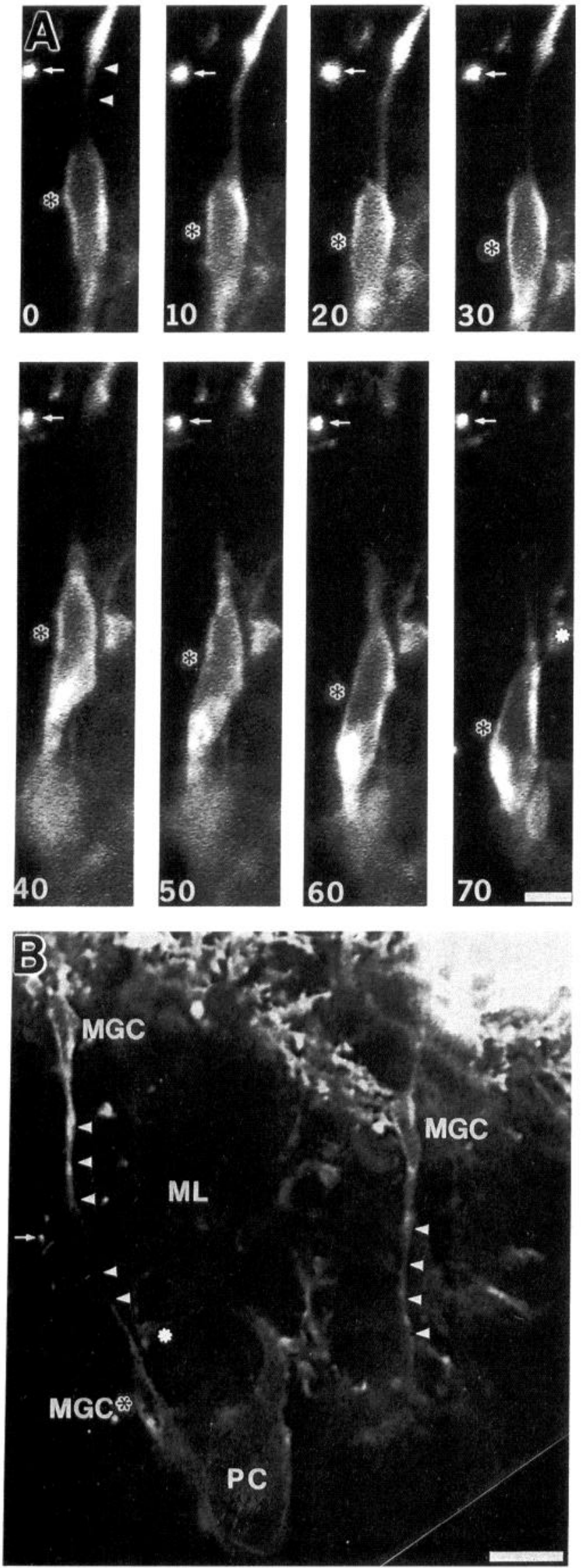

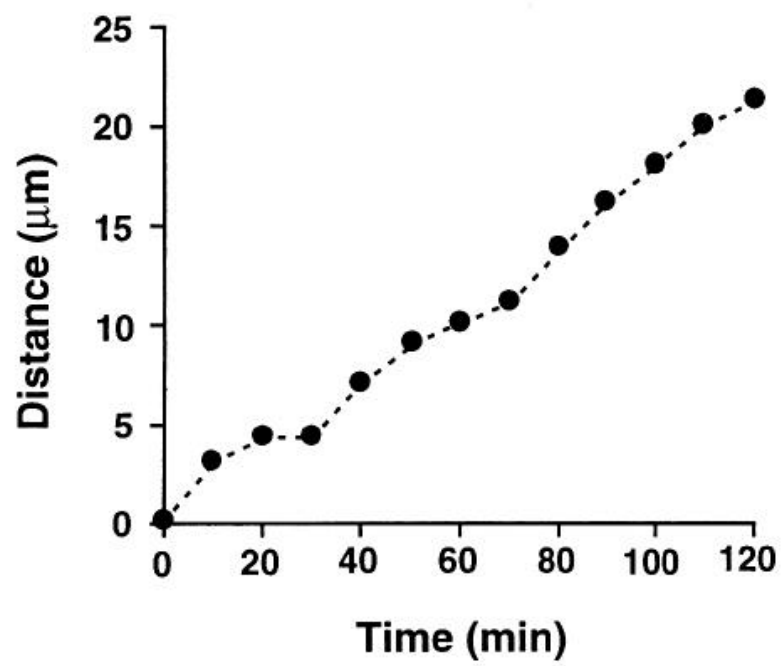

Figure 2. The distance traversed by the granule cell as a function of elapsed time. The position of the migrating granule cell was recorded at $10 \mathrm{~min}$ intervals over $120 \mathrm{~min}$. The overall rate of movement of this cell was $10.5 \mu \mathrm{m} / \mathrm{hr}$.

systematic increase in the distance traversed by granule cells with age of the animal (Fig. 4). For example, the granule cell from P8 mouse (Fig. 4A) moved a distance of $9.3 \mu \mathrm{m}$ during a $1 \mathrm{hr}$ period, while granule cells obtained from older animals moved significantly farther: the granule cell in P10 slice moved $12.1 \mu \mathrm{m}$ (Fig. $4 B$ ), the cell in P11 slice moved $17.2 \mu \mathrm{m}$ (Fig. $4 C$ ), and the cell in P12 slice moved $23.4 \mu \mathrm{m}$ (Fig. $4 D$ ) in a 1 $\mathrm{hr}$ period.

To examine the relationship between the rate of cell movement and age of cerebellum, the rate of individual granule cell movement was plotted as a function of age (Fig. 5). Although we observed considerable variation in the rate of cell movement within a given postnatal day, the overall rate of cell movement gradually and systematically increased during the course of development. The average rate of cell movement was $9.6 \pm 3.0$ $\mu \mathrm{m} / \mathrm{hr}($ mean $\pm \mathrm{SD}, n=4)$ at $\mathrm{P} 7,10.7 \pm 2.8 \mu \mathrm{m} / \mathrm{hr}(n=10)$ at $\mathrm{P} 8,10.4 \pm 4.5 \mu \mathrm{m} / \mathrm{hr}(n=8)$ at $\mathrm{P} 9,13.3 \pm 3.5 \mu \mathrm{m} / \mathrm{hr}(n=$ 8) at $\mathrm{P} 10,14.2 \pm 5.6 \mu \mathrm{m} / \mathrm{hr}(n=6)$ at P11, $20.1 \pm 3.5 \mu \mathrm{m} / \mathrm{hr}$ $(n=9)$ at $\mathrm{P} 12$, and $18.0 \pm 2.9 \mu \mathrm{m} / \mathrm{hr}(n=6)$ at $\mathrm{P} 13$ (Fig. 5). These results suggest that during development of the mouse

Figure 1. Migrating granule cells in a slice preparation obtained from P9 mouse cerebellum. Postmitotic granule cells were labeled fluorescently with DiI and their positions in the molecular layer were visualized by laser scanning confocal microscopy. A, High-power micrographs show the translocation of a migrating granule cell. The cell body of a granule cell labeled with Dil gradually moved in the direction of the internal granular layer (toward the bottom of the photograph). The time interval is indicated in minutes at the bottom of each photograph. Note that the shape of the migrating granule cell changes during the brief period recorded. The black asterisks mark the cell body of the migrating granule cell. Small white arrows and a white asterisk mark fixed reference points in the slice. $B$, Low-power overview of the developing molecular layer, which includes the migrating granule cell (indicated by a black asterisk) shown in $A$. This optical section was obtained approximately $15 \mu \mathrm{m}$ below the slice surface, $70 \mathrm{~min}$ into the period of observation. Migrating granule cells can be identified by their position, size, characteristic bipolar shape, and thin trailing and more voluminous leading processes. Bar, $5 \mu \mathrm{m}(A), 10 \mu \mathrm{m}(B) . M G C$, migrating granule cell; $P C$, soma of the Purkinje cell; $M L$, molecular layer. White arrowheads in both $A$ and $B$ indicate the processes of the Bergmann glial cells. 

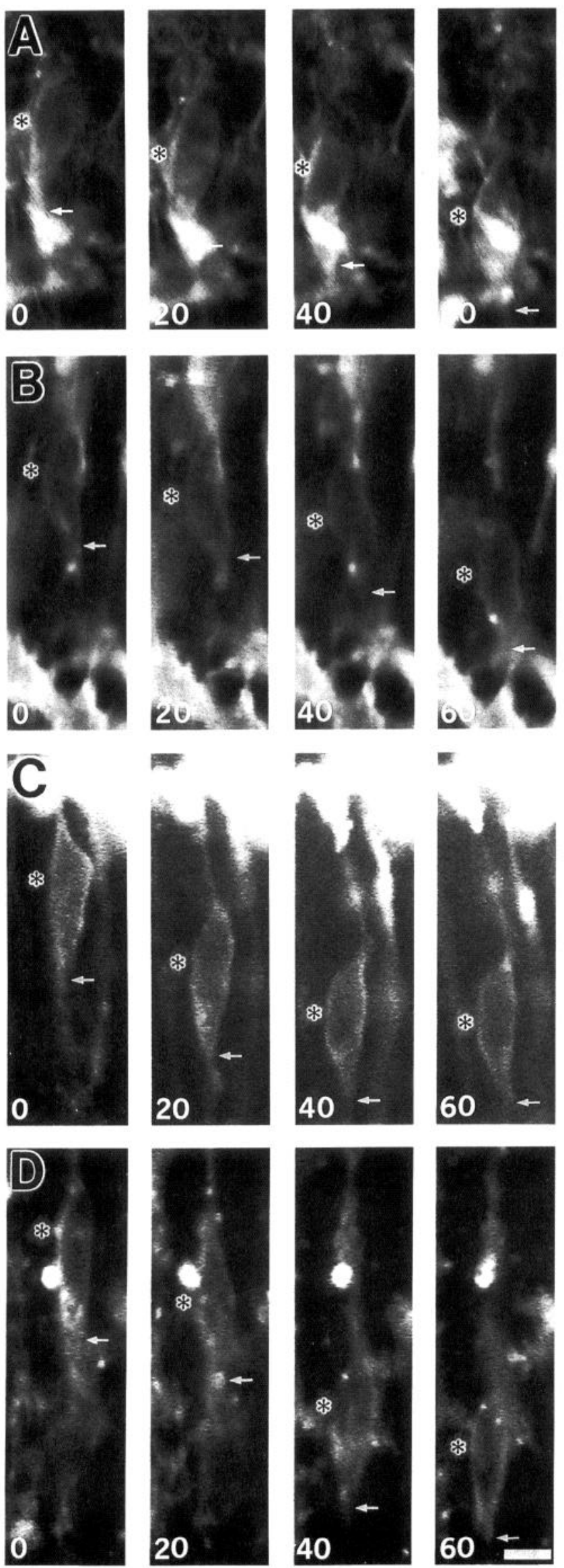

cerebellum, later-generated granule cells tend to migrate faster than earlier-generated granule cells. Although the increment in the rate of the cell movement is relatively small between successive days, the average rate in P13 mouse is about twice that recorded at $\mathbf{P} 7$.

\section{Transit time across the molecular layer}

During postnatal development, the width of the molecular layer in midsagittal cerebellum increases rapidly from about $70 \mu \mathrm{m}$ to $150 \mu \mathrm{m}$. To determine the transit time of granule cells in the expanding molecular layer, we measured the width of the molecular layer and the rate of cell movement in the cerebellar slices from the P7-13 mice. Since there is considerable variation in the width of the molecular layer between the different regions in the cerebellum, our measurements were confined to the pyramis of the anterior lobe cut coronally at the midline level. At P7 the average width of the molecular layer was $76 \mu \mathrm{m}, 89 \mu \mathrm{m}$ at $\mathrm{P} 8,104 \mu \mathrm{m}$ at $\mathrm{P} 9,111 \mu \mathrm{m}$ at $\mathrm{P} 10,123 \mu \mathrm{m}$ at $\mathrm{P} 11,132 \mu \mathrm{m}$ at $\mathrm{P} 12$, and $139 \mu \mathrm{m}$ at $\mathrm{P} 13$ (Fig. $6 \mathrm{~A}$ ). This steady increase may be attributed to the addition of parallel fibers, growth of dendritic processes of Purkinje cells, and the formation of stellate and basket cells.

To estimate the time required by granule cells to cross the entire molecular layer, the width of the molecular layer in the pyramis close to the midline was divided by the average rate of cell movement at each age group. Although there was some variation, the transit time values in all animals between $\mathrm{P} 7$ and P13 were remarkably similar (Fig. $6 B$ ). For example, the average transit time was $7.9 \mathrm{hr}$ at $\mathrm{P} 7$ mouse, $8.3 \mathrm{hr}$ at $\mathrm{P} 8,10.0 \mathrm{hr}$ at $\mathrm{P} 9,8.3 \mathrm{hr}$ at $\mathrm{P} 10,8.7 \mathrm{hr}$ at $\mathrm{P} 11,6.6 \mathrm{hr}$ at $\mathrm{P} 12$, and $7.7 \mathrm{hr}$ in P13 (Fig. 6B). These results suggest that granule cells move from the premigratory zone of the external granular layer to the internal granular layer within approximately $10 \mathrm{hr}$ after the initiation of migration, irrespective of the age of the animal and the increase in width of the molecular layer.

\section{Saltatory movement of migrating cells}

To examine the dynamics of granule cell movement in more detail, we recorded the shape and cell body displacement in the cerebellar slices at $1 \mathrm{~min}$ intervals. Figure 7 illustrates magnitude of cell body displacement of a typical fast- (Fig. $7 \mathrm{~A}$ ) and slowmoving (Fig. $7 B$ ) cell as a function of elapsed time. Although the distance traversed by both fast- and slow-moving granule cells gradually increased with passage of time, the cell body of both migrating cells did not move linearly (Fig. $7 A, B$ ). The migration speed of both cells fluctuated between phases of rapid advancement and a complete curtailment of movement.

The distance and direction attained by bodies of migrating cells during each minute of observation revealed a dynamic process characterized by the stationary periods which alternated

\footnotetext{
Figure 3. Migration rate of immature granule cells at different postnatal ages. Cerebellar slices were obtained from $\mathrm{P} 8(A), \mathrm{P} 10(B), \mathrm{P} 11$ $(C)$, and P12 mouse cerebella $(D)$. Migrating granule cells labeled fluorescently with Dil in slices were visualized by laser scanning confocal microscope. These photographs were obtained approximately $10-30 \mu \mathrm{m}$ below the slice surface. The cell body of each granule cell gradually moved in the direction of the internal granular layer (toward the bottom of each photograph). Time interval (in minutes) is indicated at the bottom of each photograph. The asterisks mark the migrating granule cell soma. Small white arrows point to the lower margin of the cell soma. Bar, $5 \mu \mathrm{m}$.
} 

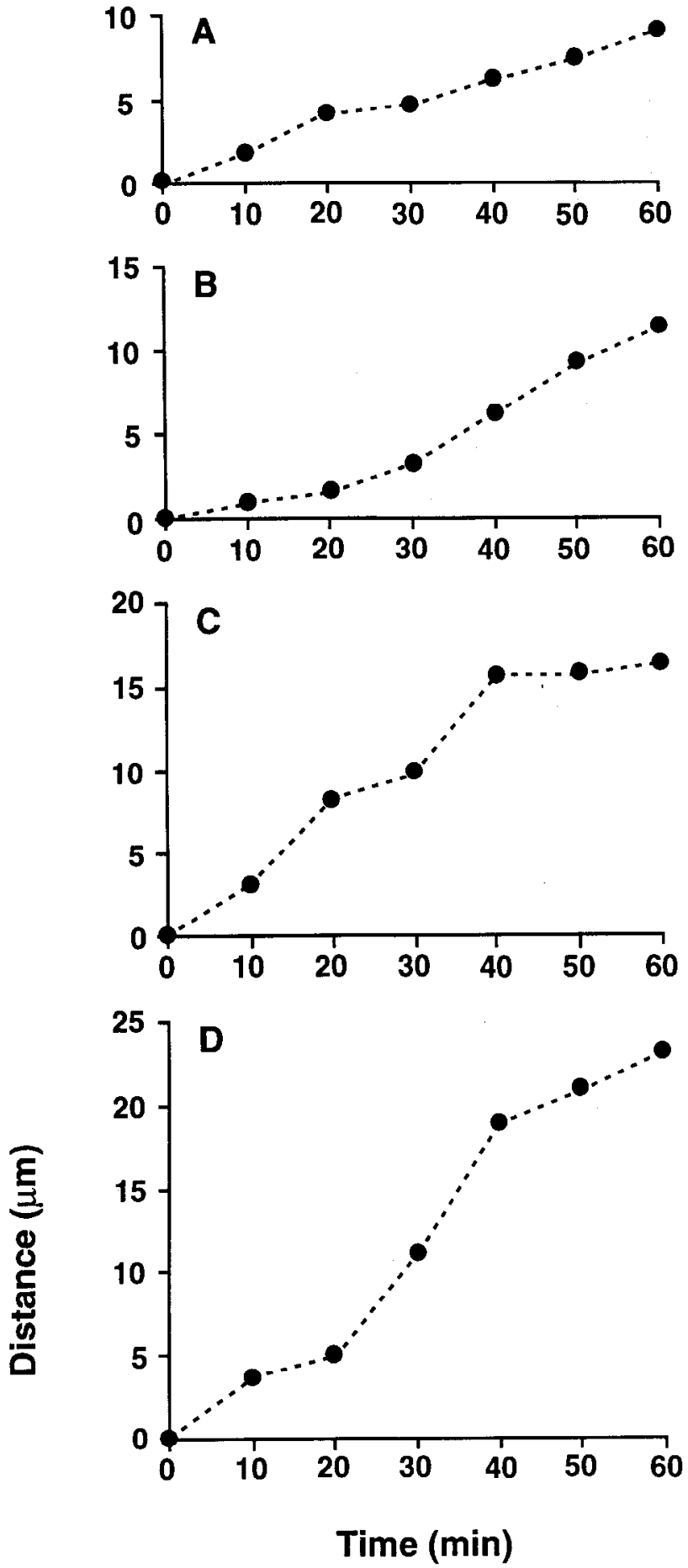

Figure 4. Graphs showing the distance traversed by the granule cells shown in Figure $3 A-D$ versus time. The overall rates of the granule cell movement were $9.3 \mu \mathrm{m} / \mathrm{hr}$ ( $A$, obtained from P8 mouse), $12.1 \mu \mathrm{m} / \mathrm{hr}$ $(B, \mathrm{P} 10), 17.2 \mu \mathrm{m} / \mathrm{hr}(C, \mathrm{P} 11)$, and $23.4 \mu \mathrm{m} / \mathrm{hr}(D, \mathrm{P} 12)$. Note that the rate of cell body movement increases during postnatal development.

with periods of either forward or backward movement (Fig. $7 C, D)$. During the 50 min of observation, the fast-moving cell exhibited a total of $33 \mathrm{~min}$ of forward movement, $7 \mathrm{~min}$ of backward movement, and $10 \mathrm{~min}$ in a stationary statc. In contrast, a slow-moving cell, during the same period, exhibited 28 min of forward movement and $11 \mathrm{~min}$ of backward movement, and spent $11 \mathrm{~min}$ in a stationary state. The distance traversed

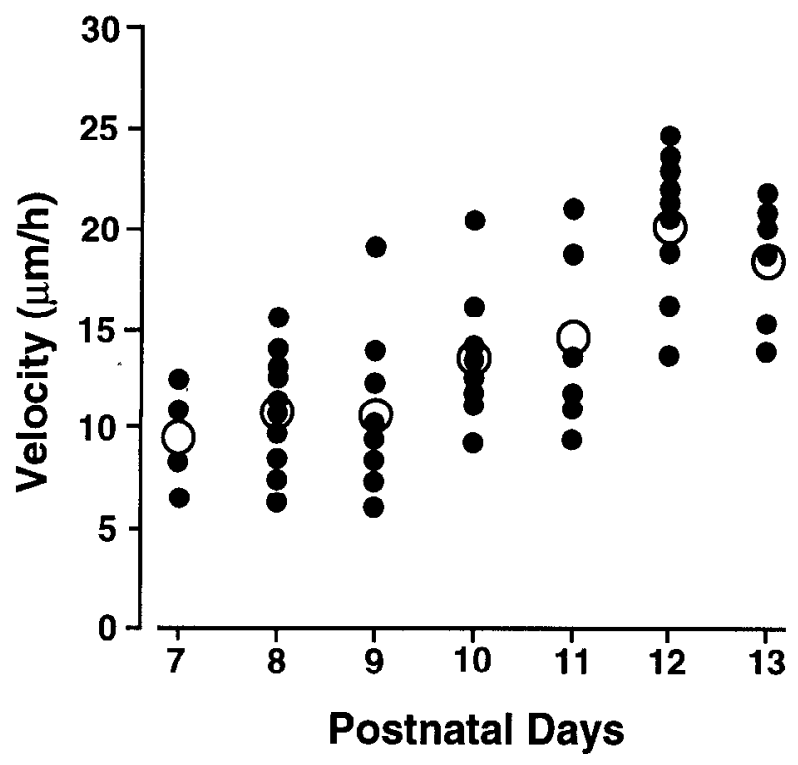

Figure 5. Increment of migration velocity in the cerebellar granule cells as a function of age. Overall velocity (rate) of cell body movement of granule cells in the molecular layer was calculated by the total distance traversed by each granule cell during the observation periods. Each $\bullet$ corresponds to the rate of cell migration obtained from a single neuron. Each $O$ represents the average rate of cell movement at each of the ages. These results suggest that the rate of granule cell movement within a given postnatal day is variable, but on the average the rate is faster in older animals than in younger.

by the fast-moving cell during each minute of forward movement was $0.5 \pm 0.4 \mu \mathrm{m}$ (mean $\pm \mathrm{SD}, n=33$ ), while the distance traversed by the slow-moving cell was $0.3 \pm 0.2 \mu \mathrm{m}(n=28)$. Taken together, the fast-moving cell had longer forward movement periods and traveled farther within each forward movement period than the slow-moving cell. These results suggest that the overall rate of granulc cell migration depcnds on both the duration and combination of periods of forward movement, backward movement, and stationary state as well as the speed of movement in each movement period.

\section{Plasma merribrane flow during cell body movement}

Studies of growth cone motility and neuronal migration have implied that the flow of the plasma membrane may direct cell movement through a combination of mechanisms that include membrane addition, deletion, and recycling (Rakic, 1985a,b; Kucik et al., 1990; Heath and Holifield, 1991; Stossel, 1993). To examine this issue, it is essential to determine the relationship between the translocation of the cell body and movement of its plasma membrane. To approach this problem, we exploited the serendipitous observation that undissolved crystals of DiI are often attached to the outer plasma membrane of migrating granule cells. These crystals could be seen as small fluorescent spots during the $5 \mathrm{hr}$ observation of the slice preparation. We were able to record the position of these spots on the plasma membrane of the cell body during active movement of individual cells. These records thus indicated the movement of the plasma membrane relative to the cell body and leading process.

Figure 8 shows an example of a migrating granule cell that has three small fluorescent spots attached on its plasma membrane. As evident in the series of micrographs, these spots (ac) did not remain at the same relative positions on the plasma 
membrane during the cell body movement. Changes in the position of these three spots are illustrated schematically and analyzed quantitatively (Fig. 9A). A substantial change in the position of these spots was observed during $5 \mathrm{hr}$. Crystal a initially moved from the middle of the cell body to the margin between soma and trailing process, but subsequently rcgaincd its starting portion. Therefore, this spot remained at the middle of the cell soma at the beginning and end of the observation period, and overall moved in concert with the cell body. Crystal b, situated initially at the border of cell soma and leading process, shifted to the center of the cell soma, but it also overall moved in concert with the movement of entire cell body. Crystal $c$, initially situated at the distal portion of the plasma membrane of the leading process, moved with respect to the cell body in a direction opposite to migration, and at the end of the observation period it was situated near the middle of cell soma. Analysis of the displacement of each spot and the cell body at shorter intervals revealed that all three spots undergo alternate forward and backward displacement while the cell body as a whole moves toward the internal granular layer (Fig. 9B). There are marked differences in the duration and combination of each period as well as in the translocated distance between the three spots. The most dramatic was the shift in position of spot $c$, from the distal scgment of the leading process to the equatorial position on the cell soma.

In slice preparations obtained from 23 postnatal P7-13 mouse cerebella, all $61 \mathrm{Dil}$ crystals initially situated within cell soma moved in concert with the cell body movement, and thus remained within the domain of the cell soma throughout a $1 \mathrm{hr}$ observation. In contrast, the majority of the DiI crystals initially situated on the leading process (25 of 29 sases) moved in an opposite direction with respect to movement of the cell body, and were subsequently found around the cell soma. The remaining four DiI crystals retained their original position on the leading process. Finally, all nine Dil crystals initially situated on the trailing process remained on the trailing process after 1 hr of observation. Throughout our experiments, neither the movement of DiI crystals from the domain of cell body to the leading process nor the movement from cell body to trailing process was recorded.

Taken together, the present results suggest that the nucleus and surrounding cytoplasm, as a whole, shift in concert with the movement of surrounding plasma membrane. The rate and direction of plasma membrane flow may depend on the position of the plasma membranc relative to the cell body of the migrating cell. In particular, the movement of some spots from the leading process to the cell soma is compatible with the hypothesis that most new membrane is added at the tip of migrating cells and passively transferred toward the cell body.

\section{Discussion}

Granule cell movement in slice preparations

The present study shows that the behavior of migrating granule cells labeled with fluorescent carbocyanine dye can be visualized in slice preparations which allow preservation of local cytoarchitectonics. Our results indicate that values for basic parameters of granule cell migration in this paradigm are comparable to those recorded in vivo. However, real-time observation of granule cell movement in the slice preparations revealed several novel aspects of cell movement, including changes in the rate of cell movement during development, constancy of the transit
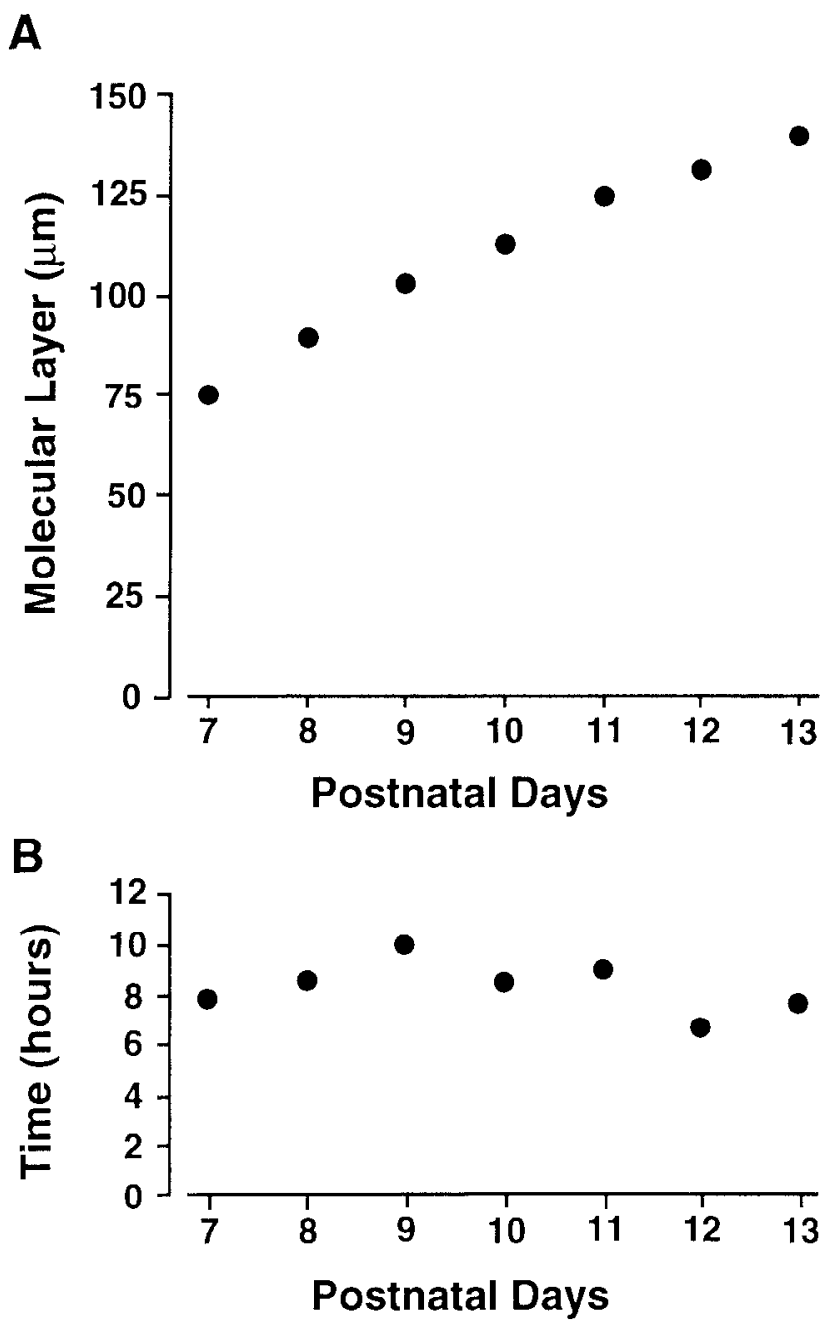

Figure 6. A, Increase of the width of the molecular layer in cerebella during the course of postnatal development. Slices were obtained from P7-13 mouse cerebella and the width of the molecular layer was measured using confocal microscopy after staining with Dil. Measurements were confined to the pyramis of the anterior lobe cut coronally at the midline. $B$, Transit time needed by postmitotic granule cells to cross the entire molecular layer as a function of postnatal days. To estimate the transit time, the width of the molecular layer in the pyramis was divided by average migration velocity obtained from Figure 5 . Notice that the transit time is relatively constant, although the width of the molecular layer expands during the postnatal development.

time across the molecular layer, saltatory pattern of cell movement, and complex flow of plasma membrane.

All migrating granule cells examined were closely apposed to the elongated processes of Bergmann glial cells and eventually shifted their somata toward the internal granular layer. The overall rate of cerebellar granule cell movement during the first $5 \mathrm{hr}$ in slice preparation was $13.9 \mu \mathrm{m} / \mathrm{hr}$, similar to the rate estimated for granule cells in vivo as well as in dissociated granule and glial cells in cultures (Fujita, 1967; Fishell and Hatten, 1991). This rate is also similar to the rate of cells migrating radially in organotypic cultures of the developing cerebral wall (O'Rourke et al., 1992). These similaritics suggest that common cellular/molecular mechanisms may control average rates of neuronal migration in the developing cerebellum and cerebrum, in spite of large differences in the length of pathways and range of speeds of individual cells. 

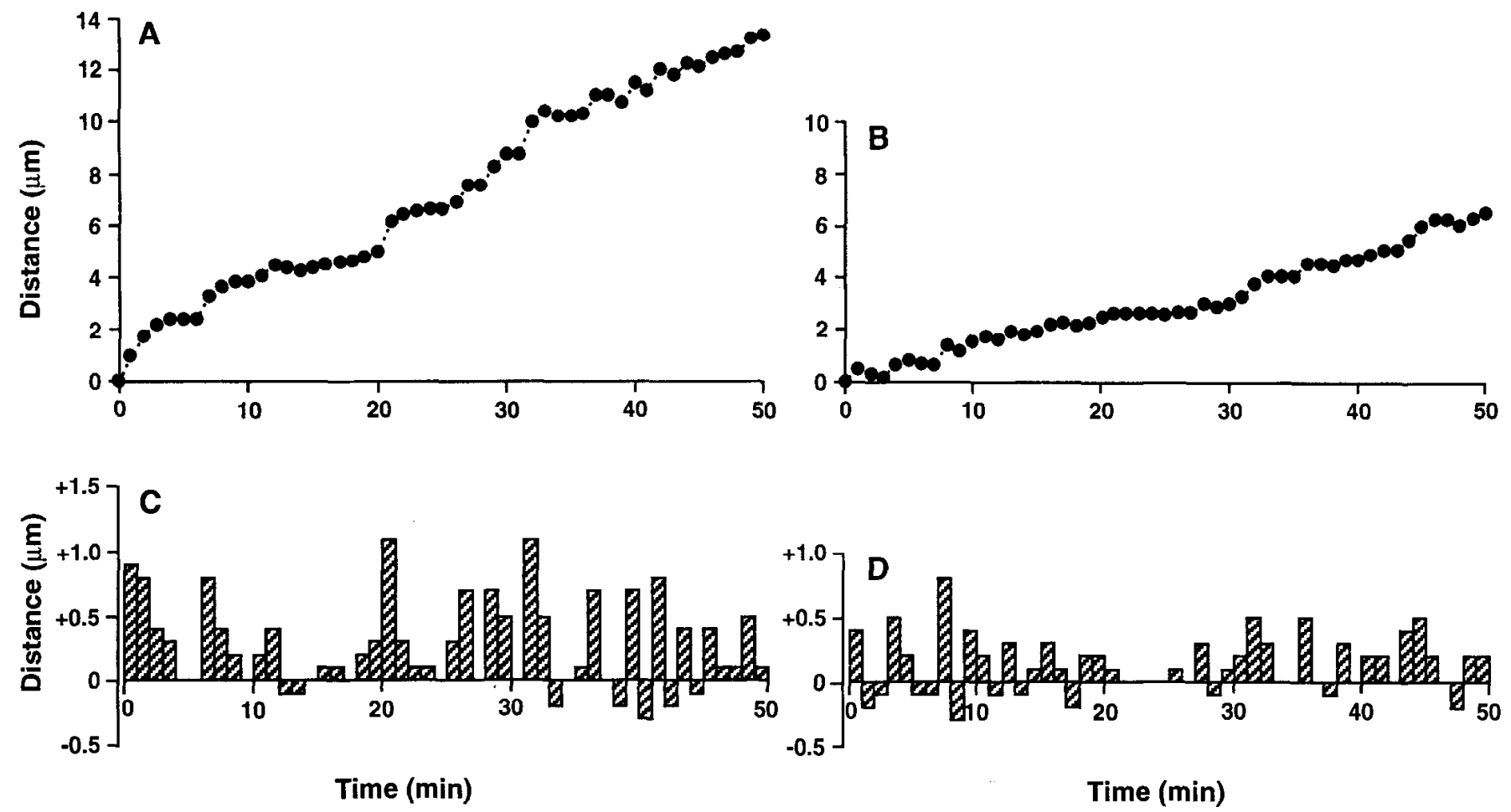

Figure 7. Graphs showing the saltatory movement of two migrating granule cells. The distances traversed by a typical fast-moving $(A)$ and a slowmoving $(B)$ migrating cell from P10 mice are plotted as a function of elapsed time. The position of the migrating granule cell body was recorded at $1 \mathrm{~min}$ intervals over a $50 \mathrm{~min}$ period. The overall rates of migration were $14.3 \mu \mathrm{m} / \mathrm{hr}$ (fast-moving cell, $A$ ) and $7.0 \mu \mathrm{m} / \mathrm{hr}$ (slow-moving cell, $B$ ). Graphs $(C, D)$ show the distance traversed by granule cells illustrating $A$ and $B$, respectively, during each minute. In this plot, positive values represent the forward movement of the granule cell body toward the internal granular layer, while negative values represent backward movement, toward the external granular layer. Note that both migrating granule cells alternate between forward and backward movement periods, and stationary periods.

\section{Age-dependent change in the rate of cell migration}

Our results show that the average rate of granule cell movement in the molecular layer increases systematically from about 9.0 $\mu \mathrm{m} / \mathrm{hr}$ at $\mathrm{P} 7$ to $18.0 \mu \mathrm{m} / \mathrm{hr}$ at P13. This increase was observed in a series of developing cerebella despite considerable variation in the rate of individual cell movement within a given postnatal day. The large change in the rate of movement over 1 week's time is surprising since one might expect that the reduction of extraccllular space in the molccular layer in older animals, caused by the addition of parallel fibers and the formation of synapses between parallel fibers and Purkinje cells, would impede latergenerated granule cells, making them slower, rather than faster.

At present, the cellular and molecular mechanisms controlling the rate of cell movement during the postnatal development are not well known. However, there are several possible explanations for the increases in the rate of cell movement at older ages. First, migrating granule cells in the molecular layer are apposed to both the processes of Bergmann glial cells, and also to the fascicles of ascending axons belonging to previously generated granule cells (shown in Fig. $15 B$ in Rakic, 1971). The number of axons associated with each Bergmann glial process increases as development proceeds. Therefore, it is possible that the expanded contact area between the later-generated granule cell and axons of earlier-generated granule cells allows an increase in the rate of cell movement, even if other conditions remain unchanged.

Another possibility is that the increase in the rate of cell migration at older ages is related to the maturity of the bio- chemical machinery that underlies cell motility. Thus, the faster cell movement at older ages may be related to an increase in the concentration of extracellular glutamate, which modulates the rate of granule cell migration by activating NMDA receptors which in turn regulate $\mathrm{Ca}^{2+}$ influx essential for cell contractility (Komuro and Rakic, 1993a). Although there is no information available about changes in the concentration of extracellular glutamate in the developing molecular layer, it is possible that glutamate levels gradually increase during the early postnatal period duc to an increase in the number and maturation of parallel fibers. On the other hand, if the sensitivity of the NMDA receptor in migrating granule cells increases during the course of development, it could account, at least in part, for the accelerated rate of cell movement in older animals, even if extracellular glutamate levels remain constant. Indeed, it has been reported that granule cells in the premigrating zone of the external granular layer in young animals are less sensitive to bathapplied NMDA than those in older animals (Rossi and Slater, 1993). Therefore, age-dependent changes in the rate of cell migration may be due to alterations in the structural and molecular environment of the expanding molecular layer as well as to changes in the biophysical properties of migrating granule cells during postnatal development.

\section{Transit time across the molecular layer}

The increase in rate of granule cell migration in older specimens may be a biological requirement for the construction of the cerebellar cortex. It has been shown that postmitotic granule cells have a restricted window of time in which they possess the 



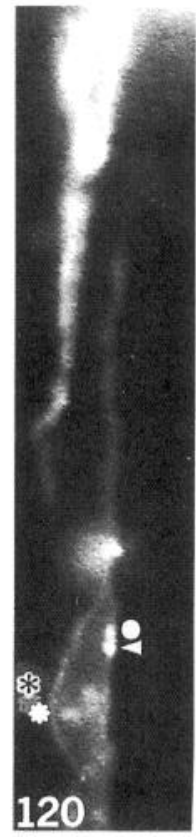

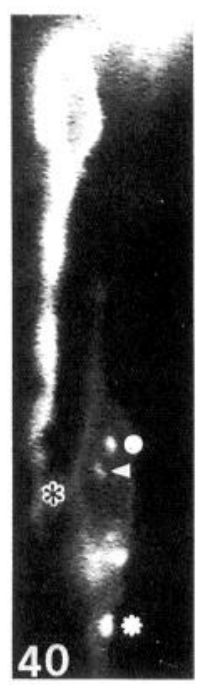
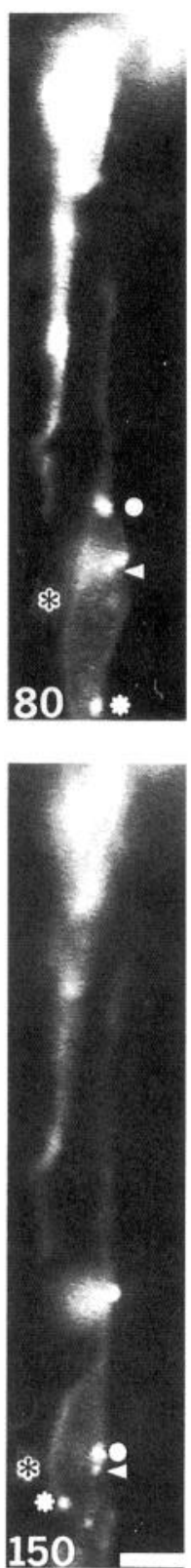

Figure 8. Translocation of the surface plasma membrane of a migrating granule cell during cell body movement. In cerebellar slice preparation of P10 mouse, small crystals of the dye DiI formed bright spots $(a, b, c)$ which allowed us to examine the displacement of the plasma membrane. Translocation of the small fluorescent spots on the plasma membrane of the migrating granule cell was visualized by laser scanning confocal microscopy and was recorded in optical sections. The bright spot $a$, indicated by a circle, is initially attached to the plasma membrane at the middle of the cell body; bright spot $b$, indicated by an arrowhead, is attached at the margin between the cell body and leading process; and bright spot $c$, indicated by a white asterisk, is attached to the plasma membrane of the leading process. Notice that the position of all three spots $(a-c)$ moved to different positions on the surface plasma membrane during the cell body's movement toward the internal granular layer (toward the bottom of the each photograph). Time interval (in minutes) is indicated on the bottom of each photograph. Bar, $5 \mu \mathrm{m}$. The black asterisks mark the cell body of the migrating granule cell. 
A
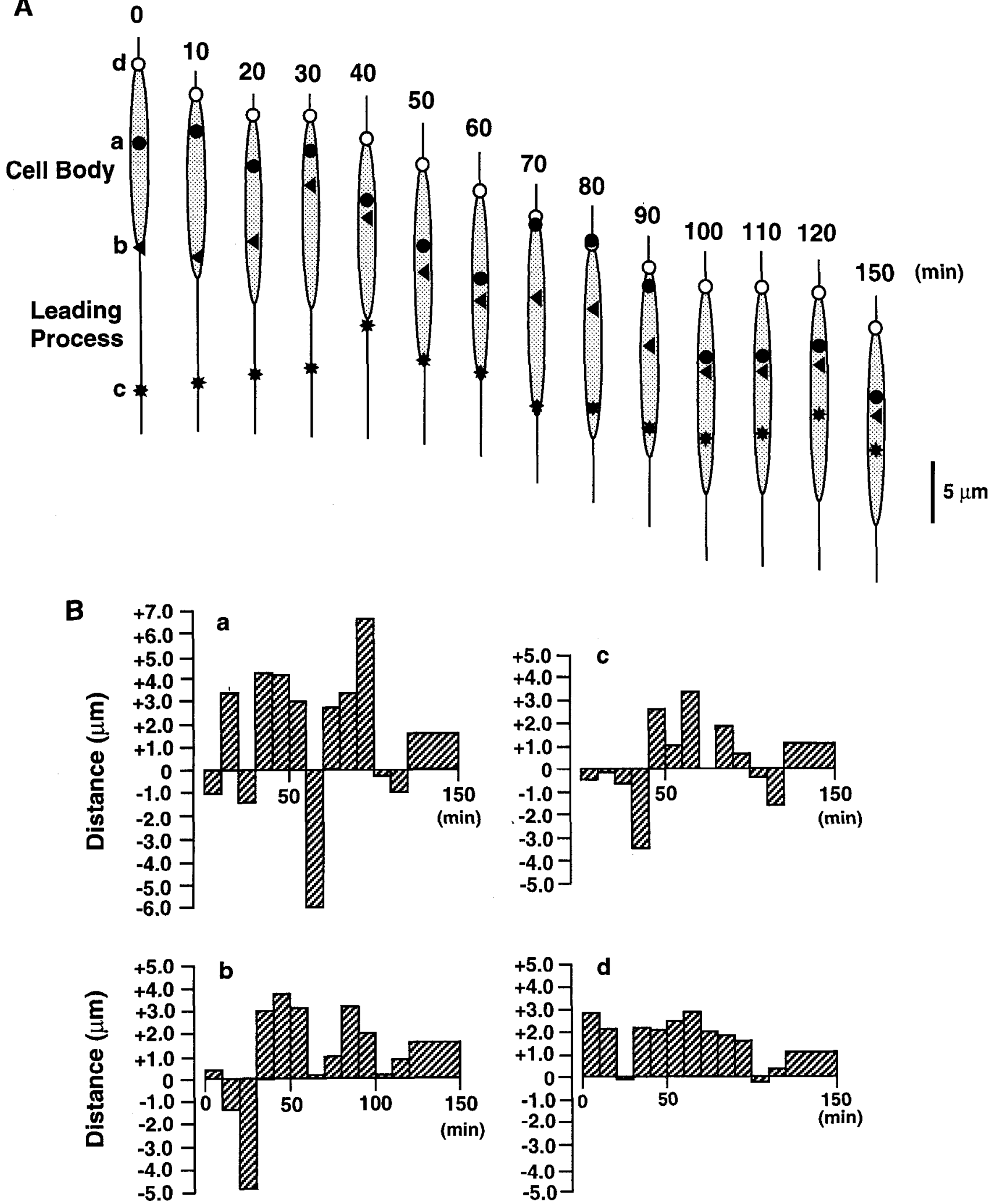

Figure 9. A, Schematic representation of the translocation of the three DiI crystals seen as fluorescent spots on the plasma membrane of the migrating cell illustrated in Figure 8 . The positions of spots designated as $a, b$, and $c$ (indicated by a filled circle, arrowhead, and asterisk, respectively) correspond to the positions of three fluorescent spots illustrated in Figure 8, and the position of $d$ (indicated by an open circle) marks the margin between the trailing process and cell body. The time interval (in min) is indicated at the top of cach drawing. $B$, Graphs showing the translocation of the three fluorescent spots $(a-c)$ and the cell body $(d)$ at intervals of 10-30 min. Positive values represent the forward translocation of the fluorescent spot (toward the internal granular layer) while negative values represent the backward movement (toward the external granular layer). All three spots on the plasma membrane alternate between forward and backward movement on the surface of the migrating cell. Notice that the translocation of $c$ was the most dramatic, and that the most new membrane was added at the segment distal to it. 
potential for migration (Trenkner et al., 1984). Therefore, as the molecular layer increases in width, it may become crucial that granule cells enhance their migration velocity in order to complete their migration within that critical period. The present results show that the transit time of granule cells across the molecular layer in the mouse cerebellum is relatively constant and ranges between $6.6-10.0 \mathrm{hr}$ during the entire postnatal period. This result stands in contrast to the $4 \mathrm{hr}$ transit time that has been estimated in vivo using the ${ }^{3} \mathrm{H}$-thymidine autoradiography in the P10 mouse cerebellum (Fujita et al., 1966).

The external granular layer in the developing cerebellum can be divided into two zones. The outer half of the external granular layer, the proliferative zonc, contains mainly dividing cells. After their final mitotic division, postmitotic granule cells become displaced to the inner half of the external granular layer, where they remain until onset of migration. Hence the term "premigratory zone." Cells remain here for $21-28 \mathrm{hr}$ before they begin to migrate across the molecular layer, toward the internal granular layer (Fujita et al., 1966; Fujita, 1967). In the study using ${ }^{3} \mathrm{H}$-thymidine autoradiography, the transient time across the molecular layer was estimated from the relationship between the position of labeled granule cells and the elapsed time after injection of ${ }^{3} \mathrm{H}$-thymidine. Thus, the estimated transient time depended upon both the length of cell cycle in the proliferative zone and transient time within the premigratory zone of the external granular layer. Therefore, it is possible that the transient time across the molecular layer as obtained from the autoradiographic study is an underestimation, due to the variability in cell cycle duration within the proliferative zone and the transient time across the premigratory zone (Fujita et al., 1966; Fujita, 1967).

\section{Saltatory movement of the migrating cells}

Studies of dissociated cerebellar cells and microexplant culture systems showed a "start-stop" pattern of granule cell movement (Edmondson and Hatten, 1987; Nagata and Nakatsuji, 1990). Migrating cells in an organotypic culture experiment using cerebral slices (O'Rourke et al., 1992) exhibit a pattern of cell movement that is similar to the movement observed in dissociated granule cells (Edmondson and Hatten, 1987). The present results, based on observations of slice preparations, show a highly dynamic tempo of granule cell migration that is characterized by stationary periods alternating with periods of either forward or backward movement. Thus, saltatory movements of the cell body within its cytoplasmic cylinder may be a ubiquitous property of migrating neurons in the developing brain.

The cellular and molecular mechanisms underlying saltatory movements of the migrating cell body are not well understood. Nonetheless, it is possible that migrating granule cells possess an intrinsic biological rhythm that directs undulation. Recently, we found that the intracellular $\mathrm{Ca}^{2+}$ level of migrating granule cells in microexplant cultures displays spontancous cyclic oscillation in both the cell nucleus and cytoplasm (Komuro and Rakic, 1993b). This cyclic periodicity of the intracellular $\mathrm{Ca}^{2+}$ level correlates with periodicity of the cell body movement (Komuro and Rakic, 1993b). Furthermore, $\mathrm{Ca}^{2+}$ influx across the plasma membrane, which is regulated by the activity of $\mathrm{N}$-type $\mathrm{Ca}^{2+}$ channels and NMDA receptors, is essential for the displacement of the granule cells (Komuro and Rakic, 1992, 1993a). Therefore, it is possible that saltatory movements of migrating granule cells are dependent upon the cyclic oscillation of intracellular $\mathrm{Ca}^{2+}$ levels, which may, in turn, be regulated by multiple intrinsic and extrinsic mechanisms including the various voltage- and ligand-activated $\mathrm{Ca}^{2+}$ channels.

\section{Plasma membrane flow during cell migration}

Although it is well established that surface area of migrating neurons substantially increases as cell soma moves across expanding spaces of the developing brain (Rakic et al., 1974), the site of new membrane addition and subsequent flow of incorporated molecules at the cell surface are not known. Our study using DiI crystals attached at the plasma membrane of migrating granule cells suggests that somatic membrane may move in register with the downward movement of the cell nucleus, and inducc mcmbrane from the leading process into the somatic membrane. Furthermore, our results are consistent with the hypothesis that new membrane is mainly deposited in the leading process and is eventually passively translocated backward. Present results are also in harmony with the conclusion based on the time-lapse microphotography of movement of glass particles attached to dissociated sympathetic neuron in culture, that new plasma membrane is deposited in the region of the growing tip of the neurite (Bray, 1970). Although our conclusion is based on the assumption that the position of DiI crystals reflects flow of cell membrane, we cannot rule out the possibility that DiI crystals embedded in the outer plasma membrane of migrating cells were anchored to the neuronal cytoskeleton through transmembrane linkage. If this were the case, the movement of the crystals would reflect the movement of the cytoskeleton rather than that of the plasma membrane (Forscher et al., 1992; Okabe and Hirokawa, 1992). However, microtubules in cultured neurons are generated in the cell body and continually translocated in an anterograde direction along the neurite (Reinsch et al., 1991; Tanaka and Kirschner, 1991). Therefore, the retrograde movement of DiI crystals which translocated from the leading process to the cell body does not reflect movement of cytoskeleton but more likely indicates plasma membrane flow.

In the present study, we could not determine whether the portion of neuronal plasma membrane attached directly to a Bergmann glial process moves in the same manner as the remaining " free" membrane, since it was not possible to label the apposed portion of the membrane. Therefore, the segments of the plasmalemmal junction between the migrating neuron and the process of a Bergmann glia cell may remain in the same position during translocation of the cell body (Rakic, 1985a,b). This is an attractive possibility, since such constant attachment can be reconciled with the role of recognition and adhesion molecules in neuronal cell migration (Rakic et al., 1994).

Taken together, our observations of migrating neurons in a slice preparation suggest that multiple cellular and molecular mechanisms may underlie the translocation of plasma membrane during cell body movement. Since plasma membrane of migrating neurons is composed of several classes of molecules including recognition receptors, cell adhesion molecules, and various ion channels (Rakic et al., 1994), it is possible that each displays a different turnover time and pattern of flow. Fluorescently labeled cerebellar slice preparation offers powerful means to address these mechanisms, but some limitations, described here, should be taken into consideration in interpreting these results.

\section{References}

Altman J (1969) Autoradiographics and histological studies of postnatal neurogenesis. Dating the time of production and onset of dif- 
ferentiation of cerebellar microneurons in rat. J Comp Neurol 136: 269-294.

Antonicek H, Persohn E, Schachner M (1987) Biochemical and functional characterization of a novel neuron-glia adhesion molecule that is involved in neuronal migration. J Cell Biol 104:1587-1595.

Bray D (1970) Surface movements during the growth of single explanted neurons. Proc Natl Acad Sci USA 65:905-910.

Cameron RS, Rakic P (1994) Identification of membrane proteins that comprise the plasmalemmal junction between migrating neurons and radial glial cells. J Neurosci 14:3139-3155.

Caviness VS Jr, Rakic P (1978) Mechanisms of cortical development: a view from mutations in mice. Annu Rev Neurosci 1:297-326.

Edmondson JC, Hatlen ME (1987) Glial-guided granule neuron migration in vitro: a high-resolution time-lapse video microscopic study. J Neurosci 7:1928-1934.

Edmondson JC, Liem RKH, Kuster JC, Hatten ME (1987) Astrotactin: a novel neuronal cell surface antigen that mediates neuron-astroglial interactions in cerebellar microcultures. J Cell Biol 106:505517.

Farrant M, Feldmeyer D, Takahashi T, Cull-Candy S (1994) NMDAreceptor channel diversity in the developing cerebellum. Nature 368 : 335-339.

Fishell G, Hatten ME (1991) Astrotactin provides a receptor system for CNS neuronal migration. Development 113:755-765.

Fishell G, Mason C, Hatten ME (1993) Dispersion of neural progenitors within the germinal zones of the forebrain. Nature 362:636-638.

Forscher P, Lin CH, Thompson C (1992) Novel form of growth cone motility involving site-directed actin filament assembly. Nature 357 : $515-518$.

Fujita $S$ (1967) Quantitative analysis of cell proliferation and differentiation in the cortex of the postnatal mouse cerebellum. J Cell Biol 32:277-287.

Fujita S, Shimada M, Nakamura T (1966) $\mathrm{H}^{3}$-thymidine autoradiographic studies on the cell proliferation and differentiation in the external and the internal granular layers of the mouse cerehellum. J Comp Neurol 128:191-208.

Gao W-Q, Hatten ME (1993) Neuronal differentiation rescued by implantation of weaver granule cell precursors into wild-type cerebellar cortex. Science 260:367-369.

Gloor S, Antonicek H, Sweadner SJ, Paglusi S, Frank R, Moos M, Schachmer M (1990) The adhesion molecule on glia (AMOG) is a homologue of the beta subunit of the Na,K-ATPase. J Cell Biol 110: 165-174.

Gregory WA, Edmondson JC, Hatten ME, Mason CA (1988) Cytology and neuron-glial apposition of migrating cerebellar granule cells in vitro. J Neurosci 8:1728-1738.

Hatten ME (1985) Neuronal regulation of astroglial morphology and proliferation in vitro. J Cell Biol 100:384-396.

Hatten ME (1990) Riding the glial monorail: a common mechanism for glial-guided migration in different regions of the developing brain. Trends Neurosci 13:179-184.

Hatten ME, Liem RKH, Mason CA (1984) Defects in specific associations between astroglia and neurons occur in microcultures of weaver mouse cerebellar cells. J Neurosci 4:1163-1172.

Hatten ME, Liem RKH, Mason CA (1986) Weaver mouse cerebellar granule neurons fail to migrate on wild-type astroglial process in vitro. J Neurosci 6:2676-2683.

Heath JP, Holifield BF (1991) Cell locomotion: new research tests old ideas on membrane and cytoskeletal flow. Cell Motil Cytoskeleton 18:245-257.

Hemmendinger LM, Caviness VS Jr (1988) Cellular migration in developing cerebral wall explants in vitro. Dev Brain Res 38:290-295.

Honig HG, Hume RI (1986) Fluorescent carbocyanine dyes allow living neurons of identified origin to be studied in long-term cultures. J Cell Biol 103:171-187.

Komuro H, Rakic P (1992) Selective role of N-type calcium channels in neuronal migration. Science 257:806-809.

Komuro H, Rakic P (1993a) Modulation of neuronal migration by NMDA receptors. Science 260:95-97.

Komuro H, Rakic P (1993b) Spontaneous calcium ion oscillation in migrating granule cells in microexplant cerebellar cultures: a laser microscopic study with calcium indicator dye Fluo-3. Soc Neurosci Abstr 19:34.

Kucik DF, Elson EL, Sheetz MP (1990) Cell migration does not produce membrane flow. J Cell Biol 111:1617-1622.

Miale LL, Sidman RL (1961) An autoradiographic analysis of histogenesis in the mouse cerebellum. Exp Neurol 4:277-296.

Monnen G, Grau-Wagemans MP, Selak I (1982) Plasminogen activator-plasmin system and neuronal migration. Nature 298:753-755.

Nagata I, Nakatsuji N (1990) Granule cell behavior on laminin in cerebellar microexplant cultures. Dev Brain Res 52:63-73.

Okabe S, Hirokawa N (1992) Differential behavior of photoactivated microtubules in growing axons of mouse and frog neurons. J Cell Biol 117:105-120.

O'Rourke NA, Dailey ME, Smith SJ, McConnell SK (1992) Diverse migration pathways in the developing cerebral cortex. Science 258 : 299-302.

Rakic P (1971) Neuron-glia relationship during granule cell migration in developing cerebellar cortex. A golgi and electron microscopic study in Macacus rhesus. J Comp Neurol 141:283-312.

Rakic $P$ (1972) Mode of cell migration to the superficial layers of foetal monkey neocortex. J Comp Neurol 145:61-84.

Rakic P (1976) Synaptic specificity in the cerebellar cortex: study of anomalous circuits induced by single gene mutation in mice. Cold Spring Harbor Symp Quant Biol 40:333-346.

Rakic P (1981) Neuronal-glial interaction during brain development. Trends Neurosci 4:189-187.

Rakic P (1985a) Contact regulation of neuronal migration. In: The cell in contact (Edelman GE, Thiery JP, eds), pp 67-90. New York: Wiley.

Rakic P (1985b) Mechanisms of neuronal migration in developing cerebellar cortex. In: Molecular bases of neuronal development (Edelman GE, Gall WE, Cowan WM, eds), pp 139-159. New York: Wiley.

Rakic P (1990) Principles of neural cell migration. Experientia 46: 882-891.

Rakic P, Sidman RL (1973a) Sequence of developmental abnormalities leading to granule cell deficit in cerebellar cortex of weaver mutant mice. J Comp Neurol 152:103-132.

Rakic P, Sidman RL (1973b) Weaver mutant mouse cerebellum: defective neuronal migration secondary to specific abnormality of Bergmann glia. Proc Natl Acad Sci USA 70:240-244.

Rakic P, Stensaas LJ, Sayre EP, Sidman RL (1974) Computer-aided three-dimensional reconstruction and quantitative analysis of cells from serial electron microscopic montages of fetal monkey brain. Nature 250:31-34.

Rakic P, Cameron RS, Komuro H (1994) Recognition, adhesion, transmembrane signaling and cell motility in guided neuronal migration. Curr Opin Neurobiol 4:63-69.

Ramon y Cajal S (1911) Histologie du system nerveux de l'homme et des vertebres, Vol 2. Paris: Maloine.

Reinsch SS, Mitchison TJ, Kirschner M (1991) Microtubule polymer assembly and transport during axonal elongation. J Cell Biol 115 : 365-379.

Roberts J, O'Rourke NA, McConnell SK (1993) Cell migration in cultured cerebral cortical slices. Dev Biol 155:396-408.

Rossi DJ, Slater NT (1993) The developmental onset of NMDA receptor channel activity during neuronal migration. Neuropharmacology 32:1 239-1248.

Sidman RL, Rakic P (1973) Neuronal migration with special reference to developing human brain: a review. Brain Res $62: 1-35$.

Stossel TP (1993) On the crawling of animal cells. Science 260:10861094.

Tanaka EM, Kirschner MW (1991) Microtubule behavior in the growth cones of living neurons during axon elongation. J Cell Biol 115:345363.

Trenkner E, Sidman R (1977) Histogenesis of mouse cerebellum in microwell cultures: cell reaggregation and migration, fiber and synapse formation. J Cell Biol 75:915-940.

Trenkner E, Smith D, Segil N (1984) Is cerebellar granule cell migration regulated by an internal clock? J Neurosci 4:2850-2855. 